\title{
Glucose-6-Phosphate Dehydrogenase and Malate Dehydrogenase Enzyme Electrophoretic Patterns Amongst Strains of Bacteroides fragilis
}

\author{
By H. N. SHAH, ${ }^{*}+$ T. A. R. AL-JALILI, K. M. ELHAG AND \\ Z. R. MUNDEGAR \\ Department of Microbiology, Faculty of Medicine, PO Box 24923, Kuwait University, 13110 \\ Kuwait
}

(Received 17 September 1986; revised 20 March 1987)

\begin{abstract}
Fifty-two strains of Bacteroides fragilis were examined for their enzyme electrophoretic patterns of glucose-6-phosphate dehydrogenase (G6PDH) and malate dehydrogenase (MDH). All strains tested possessed high levels of both enzymes but the G6PDH reduced NADP whereas MDH was NAD-dependent. Twenty-seven strains produced single bands of both G6PDH and MDH. In all cases G6PDH migrated faster than MDH. Strains clustered by a single linkage algorithm were recovered in eight clusters at the $77 \%$ similarity level. The remaining 25 strains produced multiple bands of one or both enzymes. These were recovered in six clusters at the $72 \%$ similarity level using the same algorithm. The results of this study revealed considerable heterogeneity of enzyme patterns within $B$. fragilis.
\end{abstract}

\section{INTRODUCTION}

Bacteroides fragilis is the most common species of the ' $B$. fragilis group' of species associated with infections in man. This species, however, represents only about $0.5 \%$ of the bowel microflora and is substantially outnumbered by $B$. distasonis, $B$. vulgatus and $B$. thetaiotaomicron (Moore, 1977). The clinical importance of $B$. fragilis is well documented (Gorbach \& Bartlett, 1974; Onderdonk et al., 1977; Kasper et al., 1983; Elhag et al., 1986). Early studies on more than 300 strains of $\boldsymbol{B}$. fragilis indicated that there was a continuum of variants within the species (Holdeman \& Moore, 1972). Subsequent serological studies (Elhag et al., 1977; Elhag \& Tabaqchali, 1978 $a, b$ ) and chemotaxonomic analysis (Shah \& Collins, 1980; Shah \& Williams, 1982) of $B$. fragilis further emphasized this heterogeneity. Preliminary studies in this laboratory using SDS-PAGE analysis of polypeptides and lipopolysaccharide electrophoretic patterns in silver-stained gels (unpublished data) also indicate considerable heterogeneity of $\boldsymbol{B}$. fragilis.

The value of enzyme electrophoretic patterns to investigate the suspected heterogeneity within the genus Bacteroides has been reported previously (Shah et al., 1976; Williams \& Shah, 1980; Shah \& Williams, 1982). In particular the patterns of malate dehydrogenase (MDH), glutamate dehydrogenase (GDH), glucose-6-phosphate dehydrogenase (G6PDH) and 6phosphogluconate dehydrogenase (6PGDH) have helped to clarify several chemotaxonomic problems within the pigmented and non-pigmented bacteroides (Shah \& Collins, 1983). In the present paper, we report the use of MDH and G6PDH electrophoretic patterns to probe the heterogeneity of strains of $\boldsymbol{B}$. fragilis isolated from a wide variety of clinical sites.

\section{METHODS}

Bacterial strains. All 52 strains of $B$. fragilis used in this study were of human origin. Details of the test strains and their sources are given in Table 1.

Cultivation and identification of strains. All strains were maintained by weekly subculture on $5 \%(\mathrm{v} / \mathrm{v})$ blood agar

$\dagger$ Present address: Department of Oral Microbiology, The London Hospital Medical College, Turner Street, Whitechapel, London E1 2AD.

Abbreviations: MDH, malate dehydrogenase; GDH, glutamate dehydrogenase; G6PDH, glucose-6-phosphate dehydrogenase; 6PGDH, 6-phosphogluconate dehydrogenase. 
Table 1. Strains and their sources

Reference strains: $B$. fragilis NCTC 9343, NCTC 10584, NCTC 8560 and NCTC 10581

\begin{tabular}{|c|c|c|c|}
\hline \multicolumn{2}{|r|}{ Bacteroides strain } & \multirow[b]{2}{*}{ Site of isolation } & \multirow[b]{2}{*}{ Clinical condition } \\
\hline Group & Strain & & \\
\hline $\mathbf{A}$ & $11 c, 19,20,32,43 b, 69$ & Faeces & Normal human subjects \\
\hline B & $1,26,31,65,88,112,120,121$ & Exudate (pus) & Perineal infections \\
\hline $\mathrm{C}$ & $11 b, 29,309,310,450$ & Exudate (pus) & Skin infections and submucus abscesses \\
\hline D & $2,4,6,13,15,16,34,92,280$ & Exudate (pus) & Post-operative wound infections \\
\hline $\mathbf{E}$ & $12,21 \mathrm{a}, 50,101$ & Exudate (pus) & Intra-abdominal wound sepsis \\
\hline$\overline{\mathbf{F}}$ & $5,99,102,272,273$ & Exudate (pus) & Otitis \\
\hline G & $18,39,94$ & Endocervix & Infections of female genital tract \\
\hline $\mathbf{H}$ & 49,131 & Blood & Septicaemia \\
\hline $\mathbf{U}$ & $19,23,82,98,123,21 b$ & Not known & Not known \\
\hline
\end{tabular}

plates in an atmosphere of $5 \%(\mathrm{v} / \mathrm{v}) \mathrm{CO}_{2}, 5 \%(\mathrm{v} / \mathrm{v}) \mathrm{H}_{2}$ in $\mathrm{N}_{2}$ at $37^{\circ} \mathrm{C}$ using an anaerobic cabinet (model 1028, Forma Scientific). Biochemical tests were done using the API 20A anaerobic system as described by Knivett et al. (1983). Volatile and non-volatile end products of metabolism were analysed by GLC (Elhag et al., 1986) with a Shimadzu gas chromatograph (model GC-9A). All strains were examined using these tests and only strains which accurately conformed to the description of $B$. fragilis (Holdeman et al., 1984) were included in this study.

Preparation of cell-free extracts. Cells were harvested from blood agar plates (three per strain) after $2 \mathrm{~d}$ growth under the conditions described above and suspended in $0.5 \mathrm{ml} 0.1 \mathrm{M}-\mathrm{HEPES} / \mathrm{NaOH}$ buffer, $\mathrm{pH} 7.5$. The cell suspension was shaken with Ballotini beads (grade 12) for $12 \mathrm{~min}$ in a Mickle tissue disintegrator at $4{ }^{\circ} \mathrm{C}$. After low speed centrifugation $(6000 \mathrm{~g})$ to remove the beads, the remaining unbroken cells and cell debris were removed by centrifugation at $37000 \mathrm{~g}$ for $10 \mathrm{~min}$. The supernatants, which contained between $30-50 \mathrm{mg}$ protein $\mathrm{ml}^{-1}$, were used for studies of the enzymes.

Enzyme activity and pH optimum. These were measured for only a limited number of strains to obtain the optimum conditions for electrophoretic visualization. Details of these procedures have been reported previously (Reeves et al., 1971; Shah \& Williams, 1982). All assays were done at $25^{\circ} \mathrm{C}$ using a Beckman DU-7 spectrophotometer.

Electrophoresis and staining of enzymes. Cell-free extracts were electrophoresed on Cellogel support strips, $5.7 \times 14 \mathrm{~cm}$ (Reeve Angel Scientific), as described previously (Shah \& Williams, 1982) with minor modifications. Electrophoresis was done on an LKB Multiphor unit (model 2117) with a LKB Multitemp II thermostatic circulator (model 2219$)$ at $10^{\circ} \mathrm{C}$. Electrophoresis was allowed to proceed for $1.5 \mathrm{~h}$ at $15 \mathrm{~V}(\mathrm{~cm} \text { length of gel) })^{-1}$ in 0.04 M-barbitone/acetic acid buffer, pH 8.6. NADP was used for measurements of G6PDH activity; NAD was used for MDH. The electron acceptors phenazine methosulphate and thiazolyl blue tetrazolium-MTT (BDH) were used to visualize enzymes (Shah \& Williams, 1982).

Statistical methods. Cluster analysis was used to calculate the similarities of the strains which produced single and multiple bands both of G6PDH and MDH. Before analysis, the mobility distances were standardized to give 'unit free' distances between the enzymes. The usual Euclidean distances were used to calculate the distances while the single linkage method was used for clustering of the enzymes. The Biomedical Package (BMDP, 1985) was used for this analysis.

\section{RESULTS AND DISCUSSION}

The presence of two pentose phosphate pathway enzymes, G6PDH and 6PGDH, in $B$. fragilis, $B$. thetaiotaomicron, $B$. distasonis, B. ovatus, B. vulgatus, B. eggerthii and B. splanchnicus (referred to as the ' $B$. fragilis group') has been reported previously (Shah $\&$ Williams, 1982). These enzymes were not present in other species of the genus Bacteroides and therefore appeared to be of diagnostic value for species of the 'B. fragilis group' (Shah \& Collins, 1983). MDH and GDH were also reported amongst species of the ' $\boldsymbol{B}$. fragilis group' (Shah \& Williams, 1982) and other Bacteroides species (Shah et al., 1976, 1983, 1985; Shah \& Hardie, 1979; Shah \& Collins, 1981, 1987; Haapasalo et al., 1985). The correlation between the presence of MDH and GDH and other chemotaxonomic characteristics was so significant that the occurrence of these enzymes was considered to be one of the major criteria for defining the genus Bacteroides sensu stricto (Shah \& Collins, 1983, 1987). 


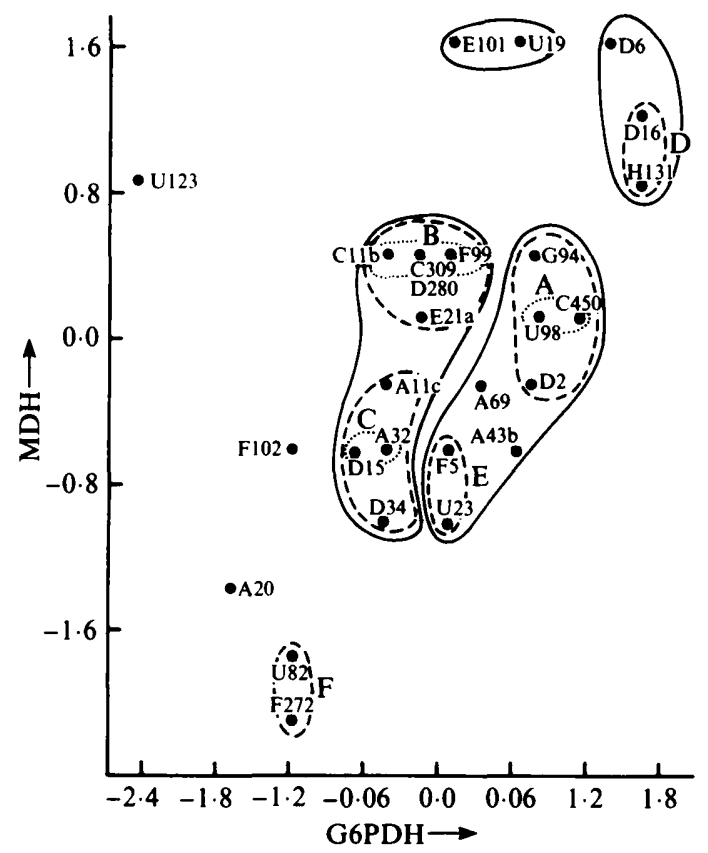

Fig. 1. Standardized electrophoretic mobilities of MDH vs G6PDH of strains which produced only single bands of both enzymes. $\cdots, 87 \%$ similarity; $\cdots, 81 \%$ similarity;,$- 77 \%$ similarity.

Table 2. Electrophoretic mobilities of $M D H$ and G6PDH of the 27 strains that had single bands only

\begin{tabular}{|c|c|c|c|c|c|}
\hline \multirow[b]{2}{*}{ Strain no. } & \multicolumn{2}{|c|}{ Electrophoretic mobility $(\mathrm{cm})$} & \multirow[b]{2}{*}{ Strain no. } & \multicolumn{2}{|c|}{ Electrophoretic mobility $(\mathrm{cm}$} \\
\hline & MDH & G6PDH & & MDH & G6PDH \\
\hline D2 & $4 \cdot 0$ & 5.8 & A69 & 4.0 & $5 \cdot 6$ \\
\hline F5 & 3.9 & $5 \cdot 5$ & U82 & 3.6 & 5.0 \\
\hline D6 & $4 \cdot 5$ & $6 \cdot 0$ & G94 & $4 \cdot 2$ & 5.8 \\
\hline Cllb & $4 \cdot 2$ & $5 \cdot 3$ & U98 & $4 \cdot 1$ & 5.8 \\
\hline Allc & 4.0 & $5 \cdot 3$ & F99 & $4 \cdot 2$ & 5.5 \\
\hline D15 & 3.9 & $5 \cdot 2$ & E101 & 4.5 & 5.5 \\
\hline D16 & $4 \cdot 4$ & 6.1 & F102 & 3.9 & 5.0 \\
\hline U19 & 4.5 & $5 \cdot 7$ & U123 & $4 \cdot 3$ & 4.5 \\
\hline A20 & $3 \cdot 7$ & $4 \cdot 8$ & H131 & $4 \cdot 3$ & $6 \cdot 1$ \\
\hline E21a & $4 \cdot 1$ & $5 \cdot 4$ & F272 & 3.5 & 5.0 \\
\hline $\mathrm{U} 23$ & 3.8 & 5.5 & D280 & $4 \cdot 2$ & 5.4 \\
\hline A 32 & 3.9 & $5 \cdot 3$ & C309 & $4 \cdot 2$ & 5.4 \\
\hline D34 & 3.8 & $5 \cdot 3$ & C450 & $4 \cdot 1$ & 5.9 \\
\hline A43b & 3.9 & $5 \cdot 7$ & & & \\
\hline
\end{tabular}

The restriction of G6PDH and $\mathrm{MDH}$ to the ' $B$. fragilis group' was recently pursued by Rogemond \& Guinet (1985). Antigenic extracts of MDH and G6PDH were detected by crossed immunoelectrophoresis in all species of the ' $B$. fragilis group' except $B$. vulgatus and $B$. distasonis which lacked G6PDH antigenic specificity. Both MDH and G6PDH showed more electrophoretic heterogeneity (unpublished data; Shah \& Williams, 1982) than 6PGDH and GDH and were therefore used in the present study to probe the enzyme polymorphism of strains of $\boldsymbol{B}$. fragilis for subsequent epidemiological studies of $\boldsymbol{B}$. fragilis virulence.

Of the 52 strains used in this study, all possessed high levels of both G6PDH [ $>120 \mathrm{nmol}$ NADP reduced (mg protein) $\left.)^{-1} \mathrm{~min}^{-1}\right]$ and $\mathrm{MDH}\left[>150 \mathrm{nmol}\right.$ NAD reduced (mg protein ${ }^{-1}$ 


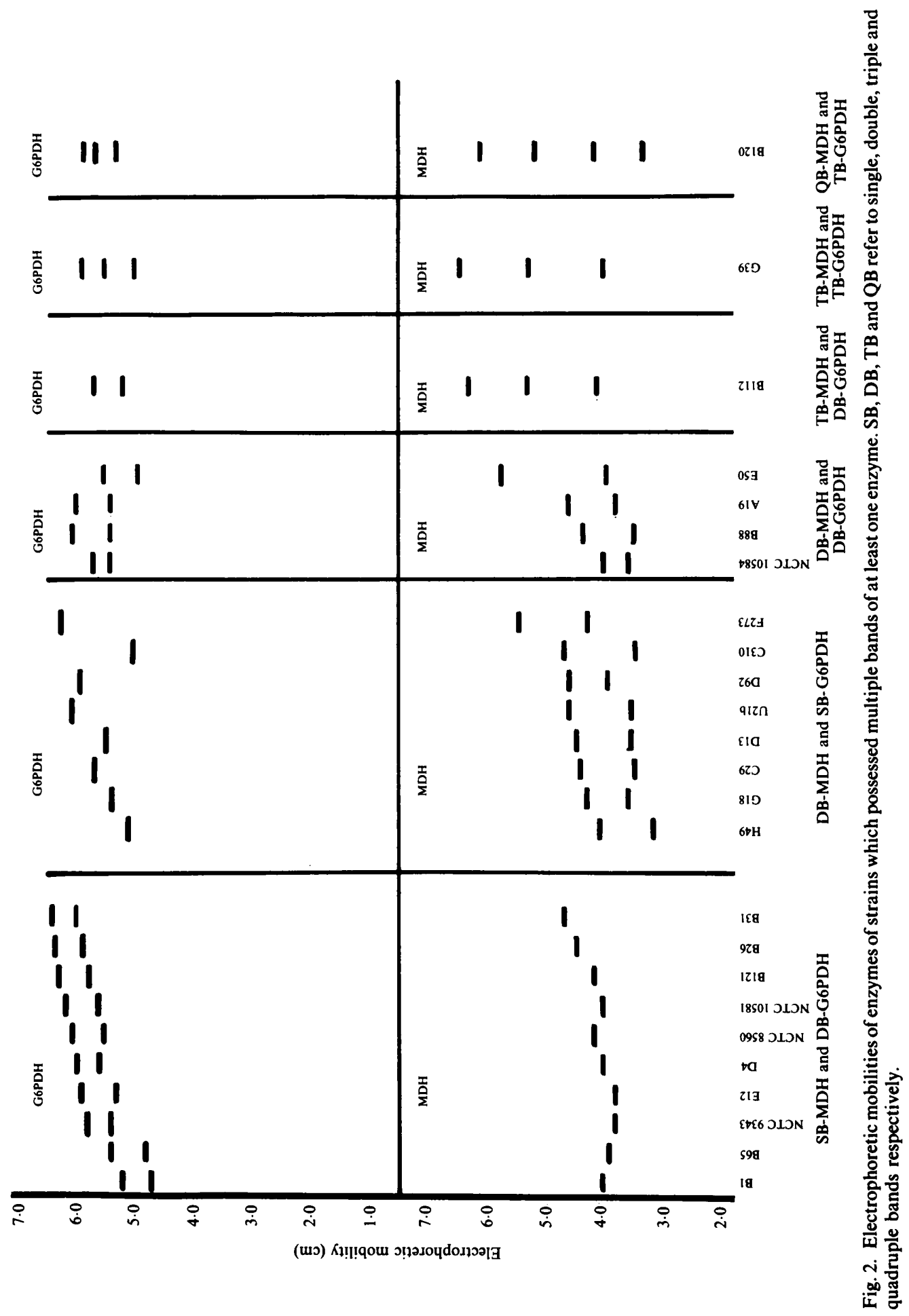




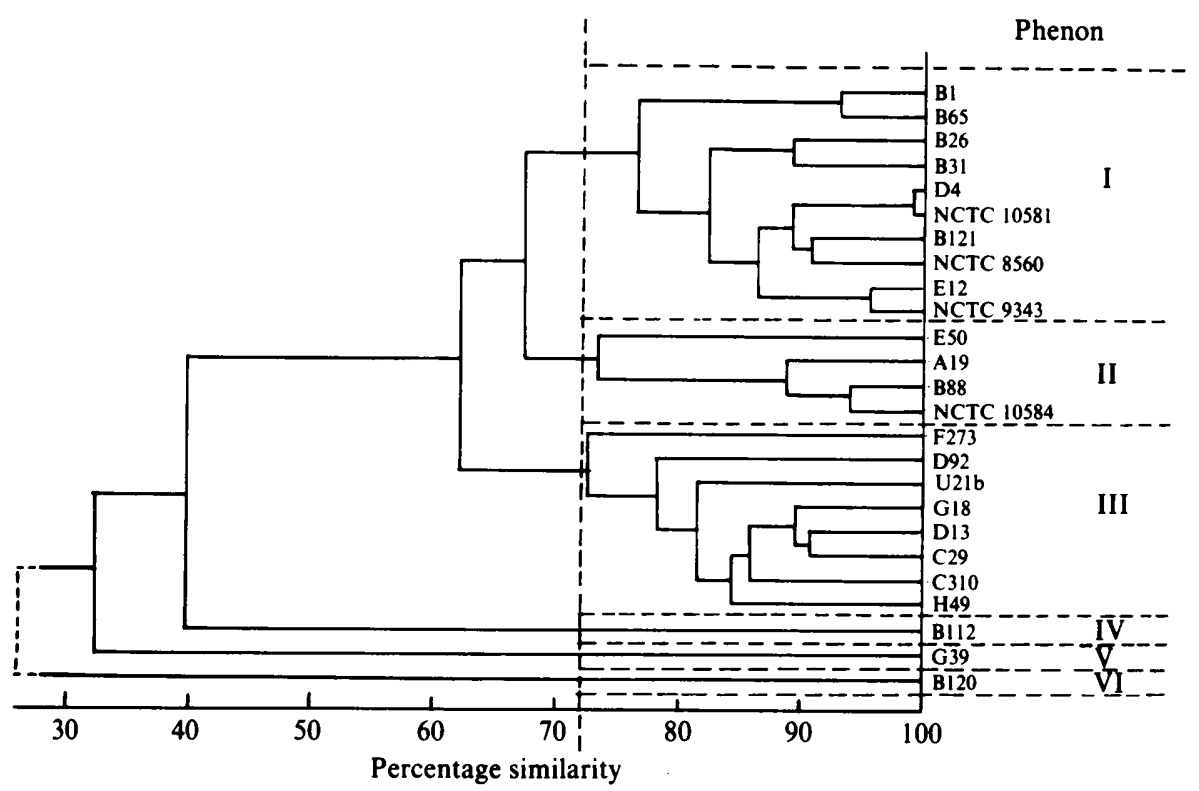

Fig. 3. Dendrogram of 25 strains of $B$. fragilis which possessed multiple electrophoretic bands of MDH or G6PDH or both.

$\min ^{-1}$ ]. All strains of $B$. fragilis tested for the presence of G6PDH required NADP as coenzyme whereas the MDH enzyme was NAD dependent.

Twenty-seven strains produced only single bands of both G6PDH and MDH. The electrophoretic mobilities of these strains are given in Table 2. In all cases G6PDH migrated faster than MDH. The enzyme mobilities for MDH ranged between 3.5 and $4.5 \mathrm{~cm}$ whereas the G6PDH enzymes migrated between 4.5 and $6.1 \mathrm{~cm}$ (Table 2). However, the electrophoretic similarity between strains were not clearly discernible from these results. For each strain a standardized migration distance was derived for both MDH and G6PDH and the data were subjected to cluster analysis (Fig. 1). At the $87 \%$ level of similarity, three clusters were formed, and arbitrarily labelled A, B and C (Fig. 1). When the similarity level was decreased to $81 \%$, cluster A encompassed strains G94 and D2, strain E21a was included in cluster B, while strains A11c and D34 were circumscribed with cluster $C$. In addition, new clusters labelled D, E and F were formed. At the $77 \%$ similarity level strains E101 and U19 clustered together and three other clusters were formed (Fig. 1) which were amalgamations of $\mathrm{A}$ and $\mathrm{E}, \mathrm{B}$ and $\mathrm{C}$ and an enlargement of D. Strains F102, A20 and particularly U123 appeared to be atypical and did not amalgamate with any of the above clusters.

Of the strains used in this study, 25 gave multiple bands of one or both enzymes. The exact relative mobilities of all strains compared to reference strains NCTC 8560 and NCTC 9343 are shown in Fig. 2. Ten strains produced single bands of MDH and double bands of G6PDH. Of the eight strains from perineal infections (labelled B) five fell into this category while the three remaining strains also had multiple bands of G6PDH (Fig. 2). Eight strains had the reverse enzyme pattern of multiple MDH bands with a single G6PDH band. Only four strains possessed double bands of both enzymes. Strains B112, G39 and B120 were atypical in possessing three or more bands of one or both enzymes (Fig. 2).

Simple comparisons between strains and their inter-relationships with each other were not easily perceptible: hence a cluster analysis of the enzyme patterns was done. Fig. 3 shows a dendrogram of the 25 strains. The dendrogram was subdivided into six clusters at the $72 \%$ level of similarity. Strains which possessed a single MDH-double G6PDH enzyme pattern clustered in phenon I which also contained three reference strains (Fig. 3). Phenon II formed a compact cluster which contained only the strains which possessed double bands of both enzymes. Strains 
which had a double MDH-single G6PDH pattern were recovered in phenon III, with strain F273 showing the lowest affinity with the group. Strains B112, G39 and B120 were resolved separately (Fig. 3); they were also different in their enzyme electrophoretic patterns from all other strains studied.

The results of the present study confirmed the suspected heterogeneity of $B$. fragilis strains. However, these electrophoretic variants may result from as little as one amino acid substitution in the enzyme molecule which represents only a very small part of the bacterial genome. The stability of these electrophoretic groups must therefore be confirmed by other well established chemotaxonomic criteria such as lipid composition and DNA:DNA hybridization. The electrophoretic patterns, however, provide a useful basis for selecting strains for DNA :DNA hybridization. This approach has been successful in resolving major taxonomic dilemmas among other species of the genus Bacteroides, for example the controversy surrounding $\boldsymbol{B}$. oralis and similar taxa (Shah et al., 1982, 1985; Shah \& Collins, 1981; Watabe et al., 1983; Haapasalo et al., 1986). Among the pigmented asaccharolytic species two taxa were clearly discerned using these methods (Shah et al., 1976), which led to the recognition of $B$. gingivalis and $B$. asaccharolyticus (Coykendall et al., 1980; Finegold \& Barnes, 1979). The combined use of G6PDH, 6PGDH, MDH and GDH for discriminating amongst species of the ' $B$. fragilis group' has already been established (Shah \& Williams, 1982); however, the full potential of MDH and G6PDH for use in assessing the heterogeneity of $B$. fragilis should await the outcome of DNA:DNA hybridization experiments.

This work was supported by Kuwait University Research Council Grant No. MI033. We thank Dr Senthilselvan for his help in the analyses of the data.

\section{REFERENCES}

BMDP Statistical Software Manual (1985). California: University of California Press.

Coykendall, A. L., Kaczmarek, F. S. \& Slots, J. (1980). Genetic heterogeneity in Bacteroides asaccharolyticus (Holdeman \& Moore, 1970) Finegold \& Barnes, 1977 (Approved Lists, 1980) and proposal of Bacteroides gingivalis sp. nov. and Bacteroides macacae (Slots \& Genco) comb. nov. International Journal of Systematic Bacteriology 30, 559-564.

Elhag, K. M.\& TABAQChali, S. (1978a). A study of the surface and somatic antigens of Bacteroides fragilis. Journal of Hygiene 80, 439-449.

Elhag, K. M. \& TabaQchali, S. $(1978 b)$. The distribution of Bacteroides fragilis serotypes amongst clinical isolates. Journal of Hygiene 81, 80-87.

Elhag, K. M., Bettelheim, K. A. \& Tabaqchali, S. (1977). Serological studies of Bacteroides fragilis. Journal of Hygiene 79, 233-241.

Elhag, K. M., Alwan, M. H., Al-Adnani, M. S. \& SHERIF, R. A. (1986). Bacteroides fragilis is a silent pathogen in acute appendicitis. Journal of Medical Microbiology 21, 245-249.

Finegold, S. M. \& BARNes, E. M. (1979). Report of the ICSB Taxonomic Subcommittee on Gram-negative anaerobic rods. Proposal that the saccharolytic and asaccharolytic strains at present classified in the species Bacteroides melaninogenicus (Oliver and Wherry) be reclassified in two species as Bacteroides melaninogenicus and Bacteroides asaccharolyticus. International Journal of Systematic Bacteriology 27, 388-391.

Gorbach, S. L. \& Bartlett, J. G. (1974). Anaerobic infections. New England Journal of Medicine 290, 1237-1245. haapasalo, M., Lounatmaa, K., Ranta, H., Shah, H. \& RANTA, K. (1985). Ultrastructure of Bacteroides capillus, B. buccae, B pentosaceus, B. oris, B. oralis, $B$. veroralis and pentose sugar-fermenting Bacteroides $s p$. from humans with periapical osteitis: occurrence of external proteinaceous cell wall layer. International Journal of Systematic Bacteriology 35, 65-72.

hacapasalo, M., Ranta, H., Shah, H., Ranta, K., LounatmaA, K. \& Kroppenstedt, R. M. (1986). Biochemical and structural characterization of an unusual group of Gram-negative anaerobic rods from human periapical osteitis. Journal of General Microbiology 132, 417-426.

Holdeman, L. V. \& Moore, W. E. C. (1972). Anaerobe Laboratory Manual. Blacksburg, Virginia: Virginia Polytechnic Institute and State University Anaerobe Laboratory.

Holdeman, L. V., Kelley, R. W. \& Moore, W. E. C. (1984). Genus 1. Bacteroides (Castellani and Chalmers 1919, 959). In Bergey's Manual of Systematic Bacteriology, vol. 1, pp. 604-631. Edited by N. R. Kreig. Baltimore: Williams and Wilkins.

Kasper, D. L., Weintraub, A., Lindberg, A. A. \& LONNGREN, J. (1983). Capsular polysaccharides and lipopolysaccharides from two Bacteroides fragilis reference strains: chemical and immunochemical characterization. Journal of Bacteriology 153, 991997.

KNivetT, V. O., Shah, H. N., MCKeE, A. S. \& Hardie, J. M. (1983). Numerical taxonomy of some nonsaccharolytic and saccharolytic Bacteroides. Journal of Applied Bacteriology 55, 71-80.

MOORE, W. E. C. (1977). Anaerobes as normal flora: gastrointestinal tract. In Proceedings of the Interna- 
tional Metronidazole Conference, pp. 222-228. Edited by S. M. Finegold. Amsterdam: Excerpta Medica.

Onderdonk, A. B., Kasper, D. L., Cisneros, R. L. \& BARTLETT, J. G. (1977). The capsular polysaccharide of Bacteroides fragilis as a virulence factor: comparison of the pathogenic potential of encapsulated and unencapsulated strains. Journal of Infectious Diseases 136, 82-89.

ReEves, H. C., RABin, R., Wegener, W. S. \& AJl, S. J. (1971). Assays of enzymes of the tricarboxylic acid and glyoxylate cycles. Methods in Microbiology 6A, 425-462.

ROGEMOND, V. \& GuINET, R. M. F. (1985). Antigens and enzymes of Bacteroides of the Bacteroides fragilis group compared by crossed immunoelectrophoresis. International Journal of Systematic Bacteriology 35, $327-332$.

Shat, H. N. \& Collins, M. D. (1980). Fatty acid and isoprenoid quinone composition in the classification of Bacteroides melaninogenicus and related taxa. Journal of Applied Bacteriology 48, 75-87.

ShaH, H. N. \& Collins, M. D. (1981). Bacteroides buccalis sp. nov., Bacteroides denticola sp. nov. and Bacteroides pentosaceus sp. nov. New species of the genus Bacteroides from the oral cavity. Zentralblatt für Bakteriologie C2, 235-241.

Shah, H. N. \& Collins, M. D. (1983). Genus Bacteroides: a chemotaxonomical perspective. Journal of Applied Bacteriology 55, 403-416.

ShaH, H. N. \& Collins, M. D. (1987). Recent advances in the chemotaxonomy of the genus Bacteroides. In Recent Advances in Anaerobic Bacteriology, 4th Biennial Symposium of the A.D.G. Cambridge: Cambridge University Press (in the Press).

ShaH, H. N. \& Hardie, J. M. (1979). Taxonomic studies on Bacteroides melaninogenicus, Bacteroides oralis, Bacteroides ruminicola and related organisms. Research and Clinical Forums 1, 51-53.

ShaH, H. N. \& Williams, R. A. D. (1982). Dehydrogenase patterns in the taxonomy of Bacteroides. Journal of General Microbiology 128, 2955-2965.

ShaH, H. N., Williams, R. A. D., Bowden, G. H. \& HARDIE, J. M. (1976). Comparison of the biochemical properties of Bacteroides melaninogenicus from human dental plaque and other sites. Journal of Applied Bacteriology 41, 473-492.

Shah, H. N., Van Steenbergen, T. J. M., Hardie, J. M. \& DE GRAAFF, J. (1982). DNA base composition, DNA-DNA reassociation and isoelectricfocusing of proteins of strains designated Bacteroides oralis. FEMS Microbiology Letters 13, 125-130.

ShaH, H. N., Collins, M. D. \& KROPPENSTEDt, R. M. (1983). Biochemical and chemical studies on Bacteroides multiacidus and Bacteroides hypermegas. Journal of Applied Bacteriology 55, 151-158.

ShaH, H. N., Collins, M. D., Watabe, J. \& MitsuOKA, T. (1985). Bacteroides oulorum sp. nov., a nonpigmented saccharolytic species from the oral cavity. International Journal of Systemic Bacteriology 35, 193-197.

Williams, R. A. D. \& Shah, H. N. (1980). Enzyme patterns in bacterial classification and identification. In Microbiological Classification and Identification, pp. 299-315. Edited by M. Goodfellow \& R. G. Board. London: Academic Press.

Watabe, J., Benno, Y. \& Mitsuoka, T. (1983). Taxonomic study of Bacteroides oralis and related organisms and proposal of Bacteroides veroralis sp. nov. International Journal of Systematic Bacteriology 33, 57-64. 